\title{
Economic Outlook and Marketing Woes on Condotel Conversions: Evidence from the Pandemic-Stricken Philippines
}

\author{
Dr. Dennis A. Sandoval, CMC, CPA \\ ASEAN Chartered Professional Accountant, Diplomate in Business Education, International Visiting Professorial Lecturer, \\ Philippines
}

\begin{abstract}
The stiff competition in the real estate industry is due to the mushrooming of small, medium, and big size developers, specifically in the Western Visayas region, in addition the global pandemic that hit the country prevented $\mathbf{T}$ Company in moving its project inventory in Aklan, for almost a year now. Therefore this resulted in negative cash flow and the company was able to survive only through the personal advances of the Board of Directors. This study hopes to address this problem by proposing a condominium to condotel project conversion. Condominium-hotels or condotels are high-rise buildings that are developed and operated as a luxury hotel, but they also have condominium units that serve as fully-functional vacation homes. Condotel units are a great investment. As a unit owner, you can live in the unit for about thirty days per year; during this time, you have access to world-class amenities. For the rest of the year, the hotel management takes over and rent it out while you earn income from it. Alternately, you can also live in the unit permanently and enjoy five-star hotel living day in, day out.
\end{abstract}

Keywords: Bubbles, Condotel, Mushrooming, Quarantine, Woes.

\section{INTRODUCTION}

The model of hotel conversion offers numerous advantages and has proven an effective bridge between risk adverse lenders and developers seeking project financing. This means that developers and condominium buyers alike value the services and branding hotel operations can bring a property.

T Company was established during the 90s of becoming one of the country's pioneering companies in wellness real estate projects. Recently, the Company launched a multi building condominium project in Aklan. To recover these costs and sustain operations it is necessary to start moving or disposing the condominium project inventory at the soonest possible time.
Further, the cash flow projection requires an injection of funds from outside sources, either from government or private financing institutions. However, to avail of developmental loans from these finance agencies, one of the major prerequisites include the sale of at least thirty percent $(30 \%)$ of the project inventory. If the development company does not do any remedial and emergency measures at this point, this prevailing situation might lead to capital losses and ultimately lead to the suspension of operations. Several options are open and one of them is to restudy the project and product concept and to convert these if necessary.

Ultimately, the purpose of the study is to determine the action plans and strategies to move the billions worth of inventory of $\mathrm{T}$ Company's project and will explore the viability of converting the project into a condotel.

\section{STATEMENT OF THE PROBLEM}

The product that was conceptualized by the management team of $\mathrm{T}$ Corporation is a residential condominium which focused on end-users specifically retirees. However, despite the Company's efforts and investments in marketing resources, no sale was produced in a year of operations. The study would like to find out whether a condo hotel conversion would be applicable for the project and finally produce the desired results that sales management have been waiting for. How can T Company move its inventory?

\section{CAUSES AND OUTLOOK OF THE PROBLEM}

\section{A. COVID 19 Economy}

Fallout of the world economic recession includes the loss of income of a great number of OFWs who had been Philippine real estate's traditional target market. The Philippine economy's best bet to shore up consumption and boost the economy overseas Filipino worker (OFW) remittances could remain weak until next year due to projected job losses and slow global economic recovery. 
ISSN (online): 2581-3048

This also means that another 400,000 OFWs could lose their jobs in 2021. This, he said, is the same number of OFWs expected to come home this year. Even majority of the upper middle income families headed by non-OFWs adopt a waitand-see attitude as most prefer to remain liquid.

Niche real estate assets will likely see greater demand after the pandemic, according to a top property consultancy firm, Business World reported. Based on the survey Santos Knight Frank conducted, half of individuals whose net worth goes over $\$ 1$ million are looking at healthcare investments. About 42 percent are eyeing offices, while 33 percent are considering real estate for retirement. Meanwhile, 25 percent of the surveyed individuals want investments focused on industrial and logistics. A number of high net worth individuals hope to upgrade their family residence, improve leisure, or facilitate permanent movement. One in every three individuals considers buying a new property for these reasons.

In terms of sentiment, these people have a soft level of optimism this year. The decline of activities in certain industries amid the pandemic caused a major blow on rich Filipinos, especially those who have investments in retail, hospitality, and aviation.

\section{B. Stiff competition from existing and established market participants}

T Company is a new developer without the luxury of the track record of more established developers. Competitive promo payment terms implemented by various developers. Commission rates for brokers have increased from the standard 5-7\% to 8-9\%. Developers are constantly increasing the incentives given to brokers

\section{Financial crisis brought about by the pandemic on tourism}

The new COVID-19 variant has caused renewed anxiety and further stalls the resumption of international travel. It is also seen to discourage domestic travel as the country extends the more stringent community quarantine qualification in major urban areas and tourist destinations, thus, further blurring the tourism industry outlook.

To help revive the hard-hit sector, the government opened "travel bubbles" in the third quarter of 2020 for tourist sites including Boracay and Palawan. Domestic tourists from anywhere in the country can enter the destinations, as long as they present negative Covid-19 tests to resorts.

To lure visitors, some companies have crafted monthly packages that will allow guests to continue working while staying at beach resorts. The attraction is undeniable, especially when rates are discounted as much as 70 per cent compared to pre-pandemic prices.

\section{Marketing Failure}

This is due to the fact that the company is new in the industry and had difficulty in building brand awareness. Another factor is the lack of a "name" in the management group. Trust is the building block in real estate and one cannot operate without it. A new developer needs a trusted name attached to the project, a seasoned marketer who has the right connections and networks.

\section{COURSES OF ACTION}

Management must study how the product can be enhanced and reclassified if necessary. In the marketing promotions of the project, condotel concept is more attractive to potential clients.

Condotels are a safe real estate investment in a day and age where other investments may seem more risky or less attractive. The condotel will generally operate like a resort hotel. There are NO association dues for condotel unit owners. Condotel unit owners can use their unit for free for 30 days, while having the remaining 335 days rented out. Rental revenue will offset some or maybe all of owner's expenses. As investors are looking at two ROI channels, first would be the property appreciation and second is the rental income from unit rentals. Lastly, condotel owners show pride of ownership, as they can say "I own a piece of a hotel".

First, an integrated marketing communications program must be in place for the next two (2) years to realize the maximum sales potential of the project. Second, the introduction of flexible payment schemes since the project is still in pre-selling stage. Third, open up the market base to include not just retirees, but yuppies, investors, and foreigners.

\section{CONCLUSION}

Originally, T Company's project was conceptualized as a residential condominium community. However, its location made it nearly impossible to sell since not many end-users are looking at Aklan as a home base. As a tourist hot spot, Aklan is known for its world-famous Boracay Resort. With this in mind, converting the condominium into a condotel would open up the Company to a broader market. Condo hotels are typically high-rise buildings developed and operated as luxury hotels, usually in major cities and resorts. These hotels have condominium units which allow someone to own a fullservice vacation home. When they aren't using this home, they can leverage the marketing and management done by the hotel 
ISSN (online): 2581-3048

Volume 5, Issue 3, pp 45-47, March-2021

https://doi.org/10.47001/IRJIET/2021.503009

chain to rent and manage the condo unit as it would any other hotel room.

\section{RECOMMENDATION}

Condo hotels are sold as second, third, fourth or fifth homes, for that matter, but they are not typically sold as primary residences. In fact, many of them limit the unit owner's usage of the unit because their unit is wanted and expected to be included in the hotel's inventory of rentable units.

The product reclassification from condominium to condotel will be an essential move for T Company. Also vital is to ensure that brokers are well-versed with the condotel product concept. Innovative strategies should also be employed to further push T Company's project.

\section{REFERENCES}

[1] Baltes, Kyle M. Use of Hotels and Other Real Estate Facilities for COVID-19 Response, Jones Day Publications, April 2020.

[2] Garcia, Leony. Ronald Lim: Father of 'condotel' concept in PHL. Business Mirror, April 7, 2015.

[3] Lopez, Elyssa. Hit by coronavirus, Philippine beach resorts target local long-stay tourists, digital nomads. South China Morning Post, February 28, 2021.

[4] Ordinario, Cai. Experts see cash flow from OFWs to trickle until 2021 on job losses | Business Mirror, December 7, 2020.

[5] Remo, Amy. Condo investments show strong returns. Philippine Daily Inquirer, November 21, 2020.
[6] Wittenburg, Kaya. ARE CONDO HOTELS A SMART INVESTMENT? www.skyfiveproperties.com/blog/condo-hotelssmart-investment, December 3, 2020.

[7] Yap, Cecilia and Lopez, Ditas. Philippine Economy Shrinks More Than Expected on Weak Demand, Bloomberg News, January 27, 2021.

[8] Zucker, Mor Why Condotels Are The Next Big Trend In Short-Term Rentals. Forbes Magazine, Feb 11, 2021.

[9] Rewards Vs. Potential Risks: Should You Invest in a Condo Hotel? https://www.condohotelcenter.com/articles/a115.html

[10] World Bank sees strong Philippine economic rebound, COVID-19 resurgence a risk, Reuters News, December 7, 2020.

\section{AUTHOR'S BIOGRAPHY}

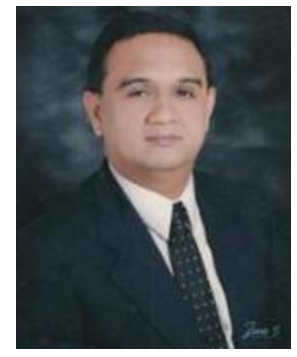

Dr. Dennis A. Sandoval, CMC, CPA received the B.S. in Accountancy degree from De La Salle University in 1993, M.B.A. degree in 1999 from Ateneo de Manila University in 1999, Doctor in Business Management degree from the Philippine Women's University in 2008, and $\mathrm{PhD}$ in Educational Management from St. Jude College-Manila in 2014. From 2009 to present, he successively served as Dean of the School of Business in three higher educational institutions in Caloocan City, City of Manila, and Quezon City. He is a lecturer of finance, accountancy, and taxation courses in some colleges and universities in Makati, Manila, and Quezon City. He is married to Liezel and has 2 daughters, Therese and Thea.

\section{Citation of this Article:}

Dr. Dennis A. Sandoval, CMC, CPA, "Economic Outlook and Marketing Woes on Condotel Conversions: Evidence from the Pandemic-Stricken Philippines" Published in International Research Journal of Innovations in Engineering and Technology IRJIET, Volume 5, Issue 3, pp 45-47, March 2021. Article DOI https://doi.org/10.47001/IRJIET/2021.503009 